\title{
Association between risk factors for coronary heart disease in schoolboys and adult mortality rates in the same localities
}

\author{
W Freeman, D C Weir, J E Whitehead, D I Rogers, S B Sapiano, C A Floyd, P M Kirk, \\ C R Stalker, N J G Field, R M Cayton, P S Burge
}

\begin{abstract}
Risk factors for coronary heart disease were compared in fifth year boys (15-16 years old) from two schools that were chosen from localities with a fourfold difference in adult mortality from coronary heart disease. One school was in an underprivileged urban locality in the area of increased incidence of heart disease ('high risk') and the other in a semirural affluent locality with an incidence of heart disease similar to the national average ('low risk'). Smoking, hypertension, hypercholesterolaemia, obesity, physical fitness, and inactivity were evaluated as risk factors for coronary heart disease. Smoking, increased body fat, poor diet, and physical inactivity were found increased among pupils from the school in the high risk area compared with those in the low risk area. Lipids, maximum oxygen uptake, and hypertension were similar in both schools. The risk of coronary heart disease seems to reflect the adult mortality rates in the area. To reduce the overall incidence of coronary heart disease, health education should be directed towards prevention of smoking, improving diets, and increasing amounts of activity among school children, with special attention directed toward children in regions where there is a high mortality from coronary heart disease among adults.
\end{abstract}

There is strong evidence that although symptoms of coronary heart disease are first noticed in adult life, the disease starts to develop during childhood, and that prevention programmes starting in childhood could reduce the death rate from cardiovascular disease. ${ }^{12}$ In adults, epidemiological studies have identified several factors that increase the risk of coronary heart disease. Hypercholesterolaemia, cigarette smoking, and hypertension are the three main factors, ${ }^{3}$ but others include obesity, ${ }^{4}$ poor physical fitness, ${ }^{56}$ and physical inactivity. ${ }^{7}$ The extrapolation of risk factors to younger age groups is speculative, but it is recognised that their identification at an early age may indicate potential candidates for coronary heart disease in adulthood. ${ }^{8}$

In the borough of Solihull (West Midlands, United Kingdom), the 1983 standard mortality ratios (SMR) for ischaemic heart disease and acute myocardial infarction compared favourably with the national average (SMR 89 and 98 , respectively). ${ }^{9}$ Mortality statistics for 1985 for people aged 50 and over within the borough of Solihull, however, identified an area with an increased death rate from coronary heart disease ( $2 \cdot 8 / 100 /$ year), compared with that of the rest of the borough $(0 \cdot 7 / 100 /$ year $)$, which was similar to the national average. In order to evaluate whether the risk factors for coronary heart disease in children reflect this difference in adult mortality, we have investigated and compared the prevalence of primary and secondary risk factors in fifth year boys attending a school in the locality with an incidence of heart disease similar to the national average with boys from a school in the locality with an increased incidence of heart disease.

\section{Methods}

Two schools were selected for study, one in the locality where the incidence of heart disease was similar to the national average (low risk school) and one in the locality where there was an increased incidence of heart disease (high risk school). The fifth year boys in each school were divided into two groups for their physical education lessons, and one class was randomly selected for study. As the stratification of the pupils for physical education lessons was not made on sporting or academic abilities, but by the school timetable, it was considered that these pupils would be representative of their total populations. A total of $42 / 45$ and $46 / 49$ pupils from the low risk and high risk schools, respectively, were studied. The study was approved by the hospital ethics committee and both parents or guardians, and pupils, gave informed consent. The assessment of each pupil included a short medical questionnaire, a series of measurements to ascertain baseline values, an activity questionnaire, and an exercise test.

The medical questionnaire listed the current and past medical history of each pupil. Resting blood pressure was measured with a manual mercury sphygmomanometer (Accoson). Hypertension was defined as a systolic blood pressure greater than or equal to $136 \mathrm{~mm} \mathrm{Hg}$ at the age of 15 years, and $142 \mathrm{~mm} \mathrm{Hg}$ at the age of 16 years, and a diastolic blood pressure greater than or equal to $86 \mathrm{~mm} \mathrm{Hg}$ at the age of 15 years, and $92 \mathrm{~mm} \mathrm{Hg}$ at the age of 16 years. ${ }^{10}$ Pupils with a history of asthma were given a $\beta_{2}$ agonist from a metered dose inhaler before exercise to minimise exercise induced bronchoconstriction. Height and weight were measured. The body mass index was calculated from the ratio of weight $/$ height $^{2}\left(\mathrm{~kg} / \mathrm{m}^{2}\right)$; a body mass index of $27 \mathrm{~kg} / \mathrm{m}^{2}$ being taken as indicating obesity. 11 Skinfold measurements were made at four sites of the body (biceps, triceps, subscapular, and suprailiac) using Harpenden calipers 
(British Indicators Ltd), which allowed the calculation of the percentage of body fat. ${ }^{12} \mathrm{We}$ defined obesity as greater than $20 \%$ body fat.

An investigator filled in the questionnaire about participation in sports outside physical education lessons. The duration, frequency, and intensity (judged by the development of sweating or breathlessness) of each sporting activity was recorded. Each pupil was then placed in one of three activity level categories: category I-aerobic activities performed three times a week for 30 minutes and associated with sweating or breathlessness, or both (the minimum amount of exercise required to develop and maintain aerobic fitness ${ }^{13}$ ); category IIaerobic activities, either performed at least once a week for 30 minutes, or three times a week for 15-30 minutes, associated with sweating or breathlessness or both; and category III-pupils who were not doing sufficient activity to be placed in the above two categories. The questionnaire also listed how the children got to and from school, other after school activities, smoking history, and father's occupation. Smoking status was verified by measuring the exhaled carbon monoxide concentration (Morgan Ecocheck-EC50), and social class was assigned by father's occupation. ${ }^{14}$

The maximal multistage 20 metre shuttle running test (20-MST) was used to assess maximum oxygen uptake. ${ }^{15}$ Each pupil ran back and forth along a 20 metre track in a gymnasium at a speed prescribed by audio signals from a prerecorded tape in a cassette recorder. The running speed for the test started at $8.5 \mathrm{~km} /$ hour with increments of $0.5 \mathrm{~km} /$ hour each minute. Pupils received continuous encouragement, and were instructed to complete as many shuttles as possible. The test was stopped either by the investigator when the pupil could not keep up with the prescribed pace, or by the pupil when he was unable to continue. Maximum oxygen uptake was predicted using the final stage and the number of shuttles completed at this stage from tables for subjects under 18 years old. ${ }^{16}$ Performance on the 20MST correlates well with the laboratory maximum oxygen uptake in boys of this age $(r=0.87)$, and is therefore a valid test to estimate maximum oxygen uptake. ${ }^{17}$ As used by Wilmore et al, a maximum oxygen uptake of less than $45 \mathrm{ml} / \mathrm{kg} / \mathrm{min}$ was regarded as a risk factor for coronary heart disease. ${ }^{18}$

Heart rate was measured at rest, at 15 second intervals throughout exercise, and for 10 minutes in recovery with a heart rate microcomputer (Sport Tester, Polar Electro). The maximum heart rate recorded at the end of exercise was compared with the predicted maximum heart rate for age $(220-$ age $) .{ }^{19}$ The rate of recovery of heart rate for each pupil was assessed by calculating the time after exercise for the heart rate to return to half of the increase observed from rest to maximum.

On subsequent occasions, two $20 \mu \mathrm{l}$ samples of capillary blood taken from the thumb were analysed for cholesterol and triglyceride concentrations with a Reflotron analyser (Boehringer). The coefficient of variation has been documented by the manufacturers as $3 \%$ for both cholesterol and triglyceride. A serum cholesterol of $5 \cdot 2 \mathrm{mmol} / \mathrm{l}$ and serum triglyceride of $2 \cdot 3$ $\mathrm{mmol} / \mathrm{l}$ were taken as the upper limits of normal. ${ }^{20}$ To assess the dietary habits of each group an investigator filled in a questionnaire recording the food consumption of each pupil over the previous 24 hours. A dietitian coded each diet into good, average, or poor using criteria recommended by the National Advisory Committee of Nutrition Education. ${ }^{21}$

The unpaired Student's $t$ test and the Wilcoxon rank sum test, when data were not normally distributed, were used to compare the discrete data between the pupils from each school. A one way analysis of variance was used when data were categorised by social class. All categorical data were analysed by the $\chi^{2}$ test.

\section{Results}

Resting measurements were made and the questionnaire given to 42 of $45(93 \%)$ and 46 of 49 (94\%) of the fifth year boys from the low risk and high risk schools, respectively. Two of the three pupils from the low risk school who did not participate in the study had been refused parental consent, and one was absent for medical reasons. Three pupils from the high risk school were absent from school for the study period for non-medical reasons (Borstal and truancy).

Table 1 shows the physical characteristics and resting blood pressure of each group. The pupils in the high risk school were significantly shorter $(95 \%$ confidence interval (CI): 0.01 to $5.9 \mathrm{~cm}$ ) and had a higher percentage of body fat ( $95 \%$ CI: 0.4 to $4.0 \%$ ) than the pupils in the low risk school. Two of 42 pupils in the low risk school (5\%) and four of 46 pupils in the high risk school $(9 \%)$ had more than $20 \%$ body fat, and by our definition were obese. The body mass index was not significantly different between schools. There were, however, three of 46 pupils from the high risk school (6.5\%) with a body mass index greater than $27 \mathrm{~kg} / \mathrm{m}^{2}$, whereas no pupils from the low risk school had body mass indexes in the obese range. The pupils in the low risk school, however, had a significantly higher mean resting systolic blood pressure (95\% CI: 0.5 to $11.5 \mathrm{~mm} \mathrm{Hg})$. In the low risk school the mean blood pressure was significantly raised in eight of 42 pupils (19\%) with four pupils having a high systolic, and four pupils having a high diastolic, pressure. Five of 46 pupils $(11 \%)$ from the high risk school were

Table 1 Physical characteristics and blood pressure measurements in fifth year boys in the low and high risk schools. Values are given as mean (SD)

\begin{tabular}{lcc}
\hline & $\begin{array}{l}\text { Boys at } \\
\text { low risk } \\
\text { school } \\
(n=42)\end{array}$ & $\begin{array}{l}\text { Boys at } \\
\text { high risk } \\
\text { school } \\
(n=46)\end{array}$ \\
\hline $\begin{array}{lll}\text { Age (years) } \\
\text { Height (m) }\end{array}$ & $15 \cdot 3(0 \cdot 5)$ & $15 \cdot 4(0 \cdot 5)$ \\
Weight (kg) & $1 \cdot 73(0 \cdot 1)^{*}$ & $1 \cdot 70(0 \cdot 1)^{*}$ \\
Body mass index (kg/m $\left.{ }^{2}\right)$ & $60 \cdot 2(7)$ & $58 \cdot 9(13)$ \\
Body fat (\%) & $20 \cdot 1(2)$ & $20 \cdot 2(4)$ \\
Systolic blood pressure & $11 \cdot 5(4)$ & $13 \cdot 7(5)^{*}$ \\
(mm Hg) & $122(11)$ & $116(14)^{*}$ \\
$\begin{array}{l}\text { Diastolic blood pressure } \\
\text { (mm Hg) }\end{array}$ & $73(10)$ & $70(13)$ \\
\hline
\end{tabular}


Table 2 Smoking history of the fifth year boys in the low and high risk schools

\begin{tabular}{lcc}
\hline & $\begin{array}{l}\text { Boys at } \\
\text { low risk } \\
\text { school } \\
(n=42)\end{array}$ & $\begin{array}{l}\text { Boys at } \\
\text { high risk } \\
\text { school } \\
(n=46)\end{array}$ \\
\hline $\begin{array}{l}\text { No (\%) current smokers } \\
\text { No (\%) who had given up smoking }\end{array}$ & $\begin{array}{r}7(17) \\
(9)\end{array}$ & $13(28)$ \\
$\begin{array}{l}\text { No (\%) who had never smoked } \\
\text { No (\%) pupils whose exhaled breath } \\
\text { contained }>64 \text { ppm carbon } \\
\text { monoxide }\end{array}$ & $31(74)$ & $22(48)^{*}$ \\
$\begin{array}{l}\text { Smokers } \\
\begin{array}{l}\text { Mean (SD) No of cigarettes/week } \\
\text { Mean (SD) duration of smoking } \\
\text { (years) }\end{array}\end{array}$ & $51(46)$ & $10(22)$ \\
\hline${ }^{*} \mathrm{p}<0.05$. & $2.7(1.8)$ & $1.5(0.9)$ \\
\hline
\end{tabular}

hypertensive, with two pupils having a raised systolic blood pressure; two pupils having a raised diastolic blood pressure, and one pupil having both raised systolic and diastolic pressures.

Table 2 shows the smoking habits of the pupils. In the high risk school more pupils were current smokers or had given up, and significantly fewer pupils had never smoked. Of the professed non-smokers, no pupil had an exhaled carbon monoxide concentration above $6 \mathrm{ppm}$, thus verifying their smoking history.

The pupils degrees of activity showed that 16 of $42(38 \%)$, and 14 of $46(30 \%)$ pupils from the low and high risk schools, respectively, were doing effective aerobic exercise at least three times a week (category I). Twelve of 42 pupils from the low risk school (29\%) and 11 of 46 pupils from the high risk school (24\%) were

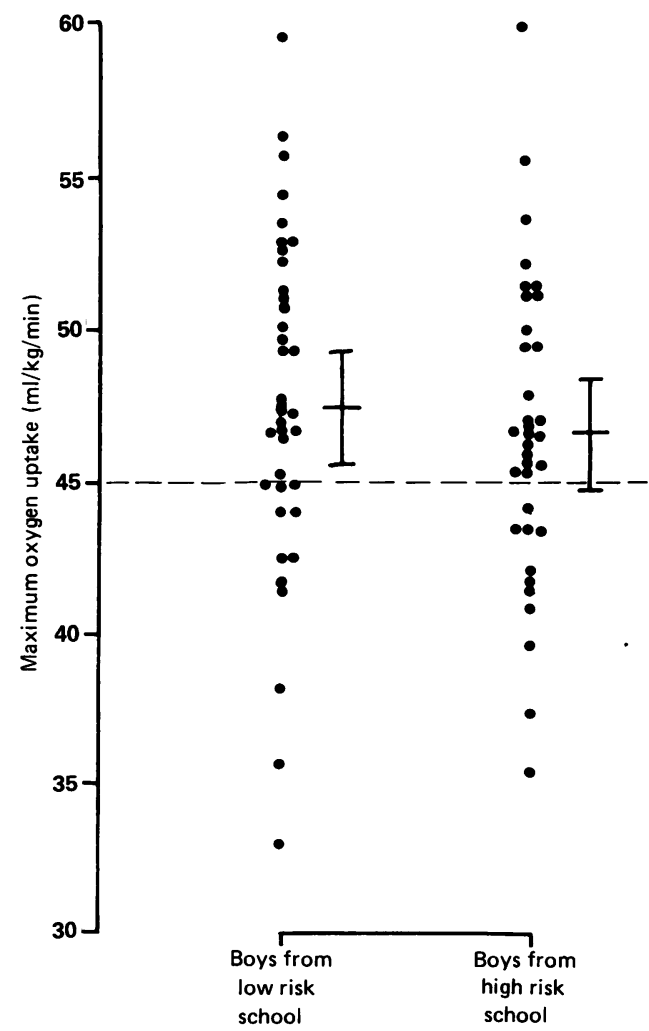

Figure 1 The maximum oxygen uptake for the fifth year boys from the low and high risk schools. Values are mean and $95 \%$ confidence intervals. The horizontal dashed line is the maximum oxygen uptake equivalent to $45 \mathrm{ml} / \mathrm{kg} / \mathrm{min}$. doing effective aerobic exercise at least once a week (category II). Fourteen of 42 pupils from the low risk school $(33 \%)$ and 21 of 46 pupils from the high risk school (46\%), however, were not performing effective aerobic exercise even once a week (category III). Of the pupils placed in category III, 12 of 14 from the low risk school $(86 \%)$ but only 10 of 21 from the high risk school $(48 \%)$ wished to increase their activity. Furthermore, more pupils from the high risk school watched three or more hours of television a night (low: 12 of 42 (29\%) compared with high: 21 of $46(46 \%))$. In contrast, 41 of 46 pupils from the high risk school walked, ran or cycled to school (89\%), compared with only 23 of 42 pupils from the low risk school (55\%) $(\mathrm{p}<0.001)$.

Thirty eight of $45(84 \%)$ and 35 of $49(71 \%)$ pupils from the low risk and high risk schools, respectively, consented to the shuttle running exercise test. There was no significant difference between the performance in the exercise test (mean (SD)) (low: 75 (20) compared with high: 71 (18) shuttles) and therefore in the estimated maximum oxygen uptake (low: $47 \cdot 5(5 \cdot 6)$ compared with high: $46.5(5 \cdot 0) \mathrm{ml} / \mathrm{kg} / \mathrm{min})$ of the fifth year boys. There was a wide range in the maximum oxygen uptake in both schools, however, with 12 of 38 pupils from the low risk school (32\%) and 11 of 35 pupils from the high risk school (31\%) having a maximum oxygen uptake less than $45 \mathrm{ml} / \mathrm{kg} / \mathrm{min}$ (fig 1 ). The average heart rates at rest, during exercise, and during recovery are shown in fig 2 . The maximum heart rates of 200 (7) (range 186-215) beat $/ \mathrm{min}$ for the low risk school and 200 (8) (range 184-219) beat/min for the high risk school, were similar. No pupil had a maximum heart rate of less than $90 \%$ of the predicted maximum, suggesting that each pupil gave maximum effort. In recovery, the time taken for the heart rate to fall to half of the increase observed from rest to maximum was not significantly different between the schools (low: 1.62 (0.55) compared with high: $1.48(0.44) \mathrm{min})$.

Four boys from the low risk school and 11 boys from the high risk school had baseline measurements taken but did not perform the exercise test. At the low risk school, three of these four boys could not undergo the exercise test for medical reasons (uncontrolled asthma, leg injury, and shoulder injury). In the high risk school, however, only one of the 11 boys could not exercise on medical grounds (congenital heart defect); the remaining 10 did not wish to undergo the test. The 10 pupils from the high risk school who did not exercise for non-medical reasons had a significantly higher percent body fat $(16.7(6.0) \%)$ than those exercising $(13.0$ $(4.5) \%)(p<0.05)$, were more likely to be current smokers (five of 10 pupils, $50 \%$ ) compared with eight of 35 (23\%) pupils who performed the exercise test, and were more inactive with six of $10(60 \%)$ pupils in activity category III, compared with 15 of 35 (43\%) pupils who exercised.

Cholesterol and triglyceride concentrations and dietary histories were obtained for 37 of 45 $(82 \%)$ and 29 of $49(59 \%)$ pupils from the low and high risk schools, respectively. The concen- 


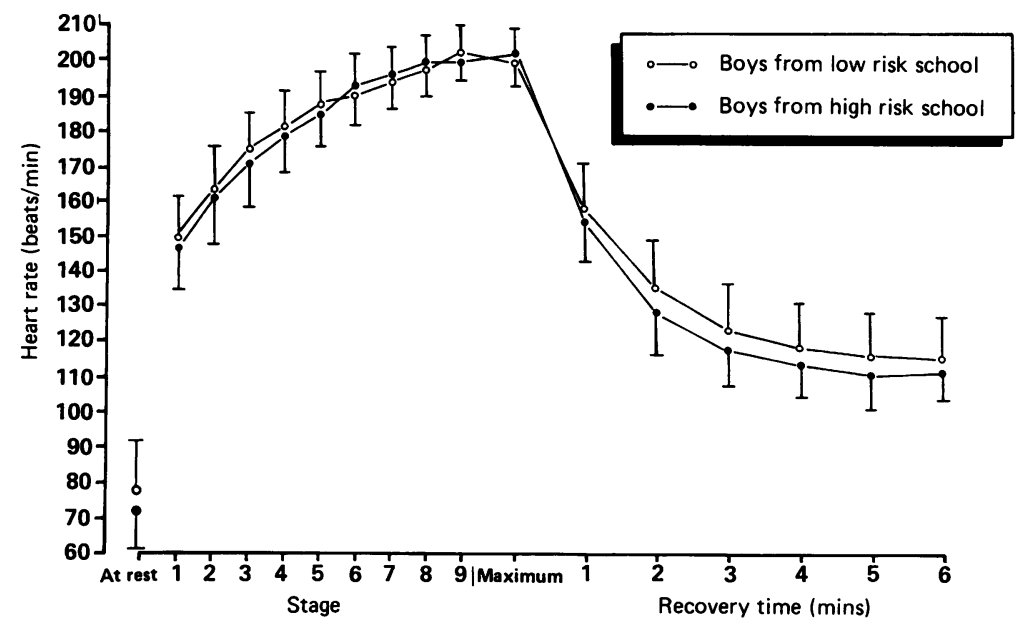

Figure 2 The mean $(S D)$ heart rate at rest, during exercise, and during recovery for the fifth year boys from the low and high risk schools.

Table 3 Prevalence (\%) of the risk factors for coronary heart disease in the fifth year boys in the low and high risk schools

\begin{tabular}{|c|c|c|}
\hline & $\begin{array}{l}\text { Boys at } \\
\text { low risk } \\
\text { school }\end{array}$ & $\begin{array}{l}\text { Boys at } \\
\text { high risk } \\
\text { school }\end{array}$ \\
\hline $\begin{array}{l}\text { Primary risk factors } \\
\text { Current smokers } \\
\text { Cholesterol concentration }>5 \cdot 2 \\
\text { mmol/l } \\
\text { Hypertension }\end{array}$ & $\begin{array}{l}7 / 42(17) \\
0 / 37 \\
8 / 42(19)\end{array}$ & $\begin{array}{l}13 / 46(28) \\
1 / 29(3) \\
5 / 46(11)\end{array}$ \\
\hline $\begin{array}{l}\text { Secondary risk factors } \\
\text { Body fat }>20 \% \\
\text { Maximum oxygen uptake }<45 \\
\mathrm{ml} / \mathrm{kg} / \mathrm{min} \\
\text { Physical inactivity (category III) }\end{array}$ & $\begin{array}{c}2 / 42(5) \\
12 / 38(32) \\
14 / 42(33)\end{array}$ & $\begin{array}{l}4 / 46(9) \\
11 / 35(31) \\
21 / 46(46)\end{array}$ \\
\hline
\end{tabular}

Table 4 Social class distribution, based on the father's occupations, of the fifth year boys from the low and high risk schools. Figures are given as No (\%)

\begin{tabular}{lcc}
\hline Social class & $\begin{array}{l}\text { Boys at } \\
\text { low risk } \\
\text { school } \\
(n=42)\end{array}$ & $\begin{array}{l}\text { Boys at } \\
\text { high risk } \\
\text { school } \\
(n=46)\end{array}$ \\
\hline I Professional & $10(24)$ & 0 \\
II Intermediate & $14(33)$ & $4(9)$ \\
IIIN (Non-manual/clerical) & $4(10)$ & 0 \\
IIIM (Manual/skilled) & $11(26)$ & $21(46)$ \\
IV Semi-skilled/manual & $2(5)$ & $6(13)$ \\
V Unskilled/manual & 0 & 0 \\
One parent (with mother) & 0 & $6(13)$ \\
Unemployed & 0 & $7(15)$ \\
Unable to code & $1(2)$ & $2(4)$ \\
\hline
\end{tabular}

trations of cholesterol (low: $3.95(0.66)$ compared with high: $4.07(0.82) \mathrm{mmol} / \mathrm{l})$ and triglyceride (low: $1.22(0.45)$ compared with high: $1 \cdot 19(0 \cdot 34) \mathrm{mmol} / \mathrm{l})$ were not significantly different between the schools. One pupil from the low risk school had a triglyceride concentration above the recommended upper limit of $2 \cdot 3$ $\mathrm{mmol} / \mathrm{l}$ and one pupil in the high risk school had a cholesterol concentration above the recommended upper limit of $5.2 \mathrm{mmol} / \mathrm{l}$. Fewer pupils from the high risk school had either a good (low: seven of 37 (19\%) compared with high: one of 29 (3\%)) or average (low: 24 of 37 (65\%) compared with high: 11 of $29(38 \%)$, $\mathrm{p}<0.05)$ diet. Indeed, the diets of 17 of 29 (59\%) pupils from the high risk school were classified as poor, compared with only six of 37 $(16 \%)$ pupils from the low risk school $(\mathrm{p}<0.001)$.

Table 3 summarises the incidence of risk factors. The primary risk factor with the highest prevalence was smoking, with a higher percentage of smokers in the high risk school. The secondary risk factors of inactivity and a maximum oxygen uptake of $<45 \mathrm{ml} / \mathrm{kg} / \mathrm{min}$ were common in both schools, with a higher percentage of the pupils in the high risk school classified as physically inactive.

Not surprisingly there were large social class differences between the pupils from the schools as determined from their father's occupation (table 4). Pupils from both schools were placed into one of three social class categories; $1=$ nonmanual workers (I, II, and IIIN); $2=$ manual workers (IIIM, IV, and V); and $3=$ others (unemployed, and pupils living with their mother). There were no significant differences in measurements analysed for social class, although there was a trend towards shorter stature, increased body fat, lower systolic blood pressure and lower maximum oxygen uptake in pupils with fathers in lower social classes (table 5). All pupils in social class category 3, however, were from the high risk school and all but four of the pupils from social class category 1 were from the low risk school. Therefore pupils from social class category 2 (manual workers-IIIM, IV, and V) in the two schools were compared. The pupils from the high risk school were shorter (low: $1.73(0.05)$ compared with high: $1 \cdot 71(0.07) \mathrm{m})$, fatter (low: $11 \cdot 8(4 \cdot 5)$ compared with high: $13.9(5.0) \%$ body fat), more inactive (low: $39 \%$ compared with high: $52 \%$ with activity category III), and there were

Table 5 Social class differences in risk factors for coronary heart disease among fifth year pupils from both schools combined. Values are mean $(S D)$ unless otherwise indicated

\begin{tabular}{|c|c|c|c|}
\hline & \multirow{2}{*}{$\begin{array}{l}l \\
\begin{array}{l}\text { Non-manual workers } \\
\text { (classes } I, I I, I I I N)\end{array}\end{array}$} & \multirow{2}{*}{$\begin{array}{l}2 \\
\text { Manual workers } \\
\text { (classes IIIM,IV, } \mathrm{V} \text { ) }\end{array}$} & \multirow{2}{*}{$\begin{array}{l}3 \\
\text { Unemployed or } \\
\text { One parent families }\end{array}$} \\
\hline & & & \\
\hline $\begin{array}{l}\text { Height }(\mathbf{m}) \\
\text { Weight }(\mathbf{k g})\end{array}$ & $\begin{array}{l}1.73(0.07) \\
60.5(9 \cdot 8)\end{array}$ & $\begin{array}{l}1 \cdot 71(0 \cdot 06) \\
59 \cdot 4(9 \cdot 4)\end{array}$ & $\begin{array}{l}1 \cdot 70(0.08) \\
59 \cdot 4(15.0)\end{array}$ \\
\hline Body fat $(\%)$ & $11 \cdot 8(3 \cdot 8)$ & $13 \cdot 2(4 \cdot 9)$ & $\begin{array}{l}59.4(15 \cdot 0) \\
13 \cdot 6(5 \cdot 2)\end{array}$ \\
\hline Systolic blood pressure $(\mathrm{mm} \mathrm{Hg})$ & $123(10)$ & $118(14)$ & $112(13)$ \\
\hline Diastolic blood pressure (mm Hg) & $74(10)$ & $71(11)$ & 69 (16) \\
\hline Cholesterol concentration $(\mathrm{mmol} / \mathrm{l})$ & $3.94(0.65)$ & $3.91(0.83)$ & $4.30(0.06)$ \\
\hline Triglyceride concentration (mmol/l) & $1.21(0.37)$ & $1 \cdot 19(0.44)$ & $1.24(0.47)$ \\
\hline Maximum oxygen uptake $(\mathrm{ml} / \mathrm{kg} / \mathrm{min})$ & $48 \cdot 3(5 \cdot 9)$ & $47 \cdot 1(4 \cdot 7)$ & $44 \cdot 4(5 \cdot 0)$ \\
\hline $\begin{array}{l}\text { Time for heart rate to return to half increase } \\
\text { observed between rest and maximum }\end{array}$ & & & \\
\hline No $(\%)$ smokers & $5 / 32(16)$ & $11 / 40(28)$ & $3 / 13(23)$ \\
\hline No (\%) inactive (category III) & $11 / 32(34)$ & $19 / 40(48)$ & $5 / 13(39)$ \\
\hline
\end{tabular}


more smokers (low: 15\% compared with high: $33 \%)$. These differences were not significant.

\section{Discussion}

We have documented the prevalence of primary and secondary risk factors for coronary heart disease in fifth year boys from two contrasting localities within a community that have a fourfold difference in mortality from coronary heart disease in adults aged 50 and over. The findings showed that there is an increased prevalence of a number of risk factors for coronary heart disease in schoolboys from the area with the higher adult death rate from coronary heart disease.

Smoking was the most prevalent of the primary risk factors in both schools, and there was a higher percentage of smokers in the high risk school. The high prevalence of smoking is relevant because the risk of coronary heart disease is proportional to the duration of smoking, and is highest in those who start before the age of 20 years. ${ }^{22}$ Furthermore a recent study has found that the protective high density lipoprotein cholesterol is reduced in children after taking up smoking, ${ }^{23}$ and thus may be contributing to the development of another risk factor for coronary heart disease.

A cholesterol concentration above $5.2 \mathrm{mmol} / \mathrm{l}$ in adults carries an increased risk of coronary artery disease. ${ }^{20}$ In our study, only one pupil (from the high risk school) had a blood cholesterol concentration above this, a finding that compares favourably with that in a group of 700 adolescents among which $9 \%$ had cholesterol concentrations above $5.2 \mathrm{mmol} / \mathrm{l}^{24}$ The measurement of total serum cholesterol may be too simplistic, ${ }^{25}$ however, and estimation of high and low density lipoprotein subfractions of cholesterol might have shown differences among the pupils. Furthermore, the dietary survey showed that children from the high risk school had much poorer eating habits, which if continued into adult life would be expected to have an adverse effect on cholesterol concentrations.

The mean systolic blood pressure was higher in the low risk pupils, which does not reflect the differences in adult mortality from coronary heart disease within the community. The reasons for this are not clear. Nevertheless, five pupils (11\%) from the high risk school and eight pupils (19\%) from the low risk school were hypertensive, although this diagnosis was based on a single measurement of blood pressure, which may have been unreliable. The prevalence of hypertension in our study was, however, similar to that in a group of 14-18 year olds in which $17 \%$ were hypertensive. ${ }^{26}$

The pupils from the high risk school were significantly shorter, which is not unexpected in view of the social class differences, but constitutes a further risk factor for coronary heart disease. ${ }^{27}$ The boys from the high risk school also had a significantly higher mean percentage of body fat, which may be attributed to their different dietary habits. The prevalence of obesity, defined as greater than $20 \%$ body fat, was higher in the schoolboys from the high risk school (9\%) compared with the pupils from the low risk school $(5 \%)$. Although the relevance of obesity as a secondary risk factor in heart disease for children is not well documented, studies suggest that $70 \%$ to $80 \%$ of obese children develop into obese adults, and therefore take this risk factor into adult life. ${ }^{28}$

Poor physical fitness has been shown to be associated with an increased risk of coronary heart disease. ${ }^{56}$ The performance on the shuttle running test and the estimated maximum oxygen uptake of the fifth year boys were not significantly different between the two schools, and was slightly inferior to that of 23 Irish schoolboys aged 15-16 years, who achieved 82 shuttles. ${ }^{29}$ About a third of the boys from both schools had a maximum oxygen uptake of less than $45 \mathrm{ml} / \mathrm{kg} / \mathrm{min}$, which is similar to the prevalence of this putative risk factor of $35 \%$ of the 308 boys aged 13-15 years quoted by Wilmore et al. ${ }^{18}$ The maximum oxygen uptake has got, however, a large inherited component. A further assessment of cardiovascular fitness was therefore made by measuring the recovery of heart rate after exercise, which also showed no significant difference between the pupils from the two schools. The results from the exercise test may, however, be biased by the higher number of boys in the high risk school who refused to take the exercise test. Baseline investigations showed that this group of boys were fatter, less active, and more were smokers.

Inactivity is associated with an increased risk of coronary heart disease. ${ }^{7}$ In this study, the amount of activity undertaken by each pupil was assessed by documenting each pupil's participation in sports, because daily activities are unlikely to raise the heart rate sufficiently to incur a training effect. ${ }^{30}$ Almost half the pupils from the high risk school and a third of the pupils from the low risk school were classified as inactive, not performing vigorous exercise even once a week. Furthermore, pupils from the high risk school watched more television, were less willing to perform the exercise test, and were more reluctant to increase the amount of activity they undertook. This negative attitude towards exercise among the pupils from the school within the area of higher adult mortality from coronary heart disease suggests that lower degrees of activity may persist into adult life, possibly leading to reduced physical fitness.

The areas from which the schools were chosen show a large difference in their degree of underprivilege, as defined by Jarman, ${ }^{31}$ although Solihull as a whole was one of the most privileged family practitioner committee areas in the UK in 1985 (97th out of 98). This disparity between the two areas within Solihull was reflected by the higher unemployment, more one parent families, and lower social class of fathers of the pupils from the high risk school, which suggests that the schools were representative of their areas.

Social class is a strong predictor of coronary heart disease. ${ }^{32}$ Adults from the lower social classes have higher rates of smoking, more obesity, and are less physically active,${ }^{33}$ which reflects the differences in risk factors found in 
our study of children. There was a trend, however, for an increase in risk factors for coronary heart disease in pupils from the same social class from the high risk school compared with the low risk school, perhaps suggesting a further environmental influence that was not accounted for by social class.

What are the interventional implications of these findings? Current studies in adults have shown little benefit of intervention on the mortality rates from coronary heart disease. ${ }^{34}$ Behaviour and attitudes that lead to an increase in the risk of coronary heart disease seem to develop in childhood, and intervention in adults may well be too late to effect change. In order to reduce the overall incidence of adult coronary heart disease more effectively, it may be wise to concentrate on the reduction of risk factors among schoolchildren, paying special attention to those in regions of higher adult mortality. The prevention of smoking is of paramount importance in reducing the incidence of coronary heart disease. In addition, the higher prevalence of obesity and poor diet among the pupils from the school in the high risk area suggests that there is a place for dietary education for both children and parents. Exercise will not only improve physical fitness but can also favourably modify the cardiovascular risk profile by reducing cholesterol and blood pressure, ${ }^{35}$ improving the high density: low density lipoprotein cholesterol ratios, ${ }^{36}$ and preventing obesity. ${ }^{37}$ The amounts of activity undertaken by the schoolchildren in our study are too low to obtain these benefits, and therefore they should be increased and then continued throughout life if protection from coronary heart disease is to be maintained. ${ }^{38}$

We thank Professor C Williams, Mr J Brewer and Mr R Ramsbottom of the department of physical education and Mr R Ramsbottom of the department of physical education and
sports science, Loughborough University, for the loan of the presports science, Loughborough University, for the loan of the pre-
recorded cassette for the shuttle running test; Mr L Almond (also recorded cassette for the shuttle running test; Mr L Almond (also
from the department of physical education and sports science, from the department of physical education and sports science,
Loughborough University) for advice on designing the questionnaire; Duncan Flockhart for the loan of the Reflotron analyser; and the pupils, physical education teachers, and headmasters of each school for their kind cooperation.

1 Kannel WB, Dawber TR. Atherosclerosis as a paediatric problem. If Pediatr 1972;80:544-54.

2 Strong WB, ed. Athersclerosis: its pediatric aspects. New York: Grune and Stratton, 1978.

3 Inter-Society Commission for Heart Disease Resources. Primary prevention of atherosclerotic diseases. Circulation 1972;42:A55.

4 Hubert HB, Feinleib M, McNamara PH, Castelli WP. Obesity as an independent risk factor for cardiovascular disease: a 26-year follow-up of participants in the Framingdisease: a 26-year follow-up of participants in the

5 Peters RK, Cady LD, Bischoff DP, Bernstein L, Pike MC. Physical fitness and subsequent myocardial infarction in Physical fitness and subsequent myocardial
healthy workers. $\mathcal{F} A M A$ 1983;249:3052-6.

6 Erikssen J. Physical fitness and coronary heart disease morbidity and mortality. Acta Med Scand 1986;711(suppl): 189-92.

7 Morris JN, Everitt MG, Pollard R, Chave SPW, Semmence AM. Vigorous exercise in leisure-time: protec-
tion against coronary heart disease. Lancet 1980;ii:1207-10.
8 Armstrong $\mathrm{N}$, Davies $\mathrm{B}$. The prevalence of coronary risk factors in children - a review. Acta Paediatrica Belgica 1980;33:209-17.

9 Statistics Division, West Midlands Regional Health Authority. Mortality in the West Midlands Region 19791983. Birmingham: West Midlands Regional Health 1983. Birmingham
Authority, 1986.

10 Task Force on Blood Pressure Control in Children. Report of the second task force on blood pressure control in the second task force on blood press
children - 1987. Pediatrics 1987;79:1-25.

11 Stewart AL, Brook RH. Effects of being overweight. Am f Public Health 1983;73:171-8.

12 Durnin JVGA, Womersley J. Body fat assessed from total body density and its estimation from skinfold thickness: measurements on 481 men and women aged from 16-72 years. $B r \mathcal{F}$ Nutr 1974;32:77-97.

13 American College of Sports Medicine. The recommended quantity and quality of exercise for developing and main taining fitness in healthy adults. Medicine and Science in Sports 1978;10:7-10.

14 Classification of occupations and coding index. London: HMSO, 1980.

15 Leger LA, Lambert L. A maximal multistage 20-m shuttle run test to predict maximum oxygen uptake. Eur $\mathcal{J} A p p l$ Physiol 1982;49:1-12.

16 Eurofit Provisional Handbook. Testing physical fitness. Strasbourg: Council of Europe, 1983.

17 van Mechelen W, Hlobil H, Kemper HCG. Validation of two running tests as estimates of maximal aerobic power in chilrunning tests as estimates of maximal aerob
dren. Eur $\mathcal{F}$ Appl Physiol 1986;55:503-6.

18 Wilmore JH, Constable SH, Stanforth PR, et al. Coronary artery disease risk factors in 13 to 15 year old boys. Med Sci Sports Exerc 1981;13:99A

19 Ashton D, Davies B. Why exercise. Oxford: Blackwell, 1986. European Atherosclerosis Society Study Group. Strategies for the prevention of coronary heart disease: a policy statement of the European Atherosclerosis Society. Eur Heart $\mathcal{f}$ 1987;8:77-88.

21 National Advisory Committee of Nutrition Education (NACNE). A discussion paper on proposals for nutritional guidelines for health education in Britain. London: Health Education Council, 1983.

22 Lee J, Lauer RM. Pediatric aspects of atherosclerosis and hypertension. Pediatr Clin North Am 1978;25:909-29.

23 Dwyer JH, Rieger-Ndakorerwa GE, Semmer NK, Fuchs R, Lippert P. Low-level cigarette smoking and longitudinal change in serum cholesterol among adolescents. FAMA change in serum

24 Drash A, Hengstenburg F. The identification of risk factors in normal children in the development of arteriosclerosis. Ann Clin Lab Sci 1972;2:348-59.

25 Castelli WP, Doyle JT, Gordon CG, et al. HDL cholesterol and other lipids in coronary heart disease. Circulation 1977; 55:767-72.

26 Lauer RM, Connor WE, Leaverton PE, Reiter M, Clarke WR. Coronary heart disease risk factors in schoolchildren. The Muscatine study. F Pediatr 1975;86:697-706.

27 Rose G, Marmot MG. Social class and coronary heart disease Br Heart f 1981;45:13-9.

28 Court JM. Prevention during childhood of ischaemic heart disease. Aust Paediatr f 1972;57:15-22.

29 Boreham CAG, Paliczka VJ, Nichols AK. A comparison of the PWC 170 and 20-MST tests of aerobic fitness in adolescent schoolchildren. $\mathcal{F}$ Sports Med Phys Fitness (in press).

30 Seliger V, Trefny S, Bartunkova S, Pauer M. The habitual activity and physical fitness of 12 year old boys. Acta activity and physical fitness of

31 Jarman B. Identification of underprivilcged areas. $\mathrm{Br}$ Med $\mathcal{F}$ 1983;286:1705-9.

32 Marmot MG, Adelstein AM, Robinson N, Rose GA Changing social class distribution of heart disease. $\mathrm{Br}$ Med f 1978;ii: 1109-12.

33 Pocock SJ, Shaper AG, Cook DG, Phillips AN, Walker M Social class differences in ischaemic heart disease in British men. Lancet 1987;ii:197-201.

34 McCormack J, Skrabanek P. Coronary heart disease is not preventable by population interventions. Lancet 1988;ii: 83941 .

35 Findlay IN, Taylor RS, Dargie HJ, et al. Cardiovascular effects of training for a marathon run in unfit middle aged men. Br Med f 1987;295:521-4.

36 Wood PD, Stefanick ML, Dreon DM, et al. Changes in plasma lipids and lipoproteins in overweight men during weight loss through dieting as compared with exercise. weight loss through dieting as comp

37 Moody DL, Wilmore JH, Girandola RN, Royce JP. The effects of a jogging programme on the body composition of effects of a jogging programme on the body composition of
normal and obese high school girls. Medicine and Science in Sports 1972;4:210-3.

38 Paffenbarger RS Jr, Hyde RT, Wing A, Steinmatz CH. A natural history of athleticism and cardiovascular health. $\mathcal{J} A M A$ 1984;252:491-5. 